\title{
Silica nanoparticles and calcium on the histological characteristics and stem bending in gerbera cut flower
}

\author{
Tahereh Tofighi Alikhani ${ }^{*}$ (), Seyed Jalal Tabatabaei² (D), Ali Mohammadi Torkashvand ${ }^{3}$ (ㅇ), and Daryush Talei ${ }^{4}$ (1) \\ ${ }^{1}$ Islamic Azad University, Science and Research Branch, Department of Horticultural Sciences, Tehran, Iran. \\ ${ }^{2}$ Shahed University Tehran, Department of Agricultural and Medicinal Plant Research Center, Tehran, Iran. \\ ${ }^{3}$ Islamic Azad University, Science and Research Branch, Department of Soil Science, Tehran, Iran. \\ ${ }^{4}$ Shahed University, Medicinal Plants Research Centre, Tehran, Iran.
}

\begin{abstract}
Silica nanoparticles and calcium are necessary for improving plant yield and decreasing stem bending in gerbera flower (Gerbera Jamesonii L.). In order to determine the optimal concentrations of silica nanoparticles and calcium in gerberas (Gerbera Jamesonii L.), a factorial experiment in the form of completely randomized design with two factors was conducted. The first factor was the concentration of silica nanoparticles (Nanoparticle-SiO $)_{2}$ at four rates $\left(0,20,40\right.$, and $\left.80 \mathrm{mg} \mathrm{L}^{-1}\right)$ and the second factor was the concentration of calcium chelate (Ca-Chelate) at four rates $\left(0,60,120\right.$, and $\left.240 \mathrm{mg} \mathrm{L}^{-1}\right)$ which were applied as nutrient solutions. After harvest, characteristics such as stem bending, cellulose content, phenyl alanine ammonia-lyase enzyme activity in leaves, and stem histological characteristics were measured. Results indicated that the lowest stem bending (deviation angle of $8.78^{\circ}$ ) was observed with applying $20 \mathrm{mg} \mathrm{L}^{-1}$ Nanoparticle-SiO and $240 \mathrm{mg}$ $\mathrm{L}^{-1} \mathrm{Ca}$-Chelate. Comparing with control, applying $80 \mathrm{mg} \mathrm{L}^{-1}$ Nanoparticle- $\mathrm{SiO}_{2}$ and $240 \mathrm{mg} \mathrm{L}^{-1} \mathrm{Ca}-\mathrm{Chelate}$ increased lignin and cellulose contents by 33 and $15 \%$, respectively. The highest amount of phenylalanine ammonia-lyase ( 2.87 units per mg of fresh leaf) was obtained by using $60 \mathrm{mg} \mathrm{L}^{-1}$ calcium chelate. According to nutrient concentrations, the change patterns of xylem and stem lignification were different, which is in line with the results of the physiological studies conducted on the effects of applying silica nanoparticle and calcium in nutrient solution. Under the epidermis, there was a hypodermis (sclerenchyma) which strengthens stem tissue. Silica nanoparticles and calcium chelate due to increasing phenylalanine ammonia-lyase content and its effect on the production cycles of cellulose and lignin and increasing stem sclerenchyma, led to stems strength and lignification, which eventually decreased stem bending. According to study results, applying $40 \mathrm{mg}$ $\mathrm{L}^{-1}$ Nanoparticle-SiO ${ }_{2}$ and $60 \mathrm{mg} \mathrm{L}^{-1} \mathrm{Ca}-\mathrm{Chelate}$ in hydroponic nutrient solution is recommended for growing gerbera flowers.

Keywords: anatomy; cellulose; hydroponics; lignin; phenylalanine ammonia-lyase enzyme.
\end{abstract}

\section{Resumo}

Nanopartículas de sílica e cálcio nas características histológicas e curvatura da haste de gérberas de corte

Nanopartículas de sílica e cálcio são necessárias para melhorar a produtividade das plantas e diminuir a curvatura da haste em gérbera (Gerbera jamesonii L.). Para determinar as concentrações ótimas de nanopartículas de sílica e cálcio na gérbera (Gerbera jamesonii L.), foi realizado um experimento fatorial na forma de delineamento inteiramente casualizado com dois fatores. O primeiro fator foi a concentração de nanopartículas de sílica (Nanopartícula-SiO $\left.{ }_{2}\right)$ em quatro doses $\left(0,20,40\right.$ e $\left.80 \mathrm{mg} \mathrm{L}^{-1}\right)$ e o segundo fator foi a concentração de quelato de cálcio (Ca-Quelato) em quatro doses $\left(0,60,120\right.$ e $\left.240 \mathrm{mg} \mathrm{L}^{-1}\right)$, as quais foram aplicados como soluções nutritivas. Após a colheita, características como curvatura da haste, conteúdo de celulose, atividade da enzima fenil alanina amonia-liase nas folhas e características histológicas do caule foram determinados. Os resultados indicaram que a menor curvatura da haste (ângulo de desvio de $8,78^{\circ}$ ) foi observada com a aplicação de $20 \mathrm{mg} \mathrm{L}^{-1}$ de Nanopartícula$\mathrm{SiO} 2$ e $240 \mathrm{mg} \mathrm{L}^{-1}$ de quelato de Ca. Em comparação com o controle, a aplicação de $80 \mathrm{mg} \mathrm{L}^{-1}$ de nanopartícula-SiO e e $240 \mathrm{mg} \mathrm{L}^{-1}$ de quelato de $\mathrm{Ca}$ aumentou os teores de lignina e celulose em $33 \%$ e $15 \%$, respectivamente. A maior quantidade de fenilalanina amania-liase (2,87 unidades por mg de folha fresca) foi obtida com o uso de quelato de cálcio $60 \mathrm{mg} \mathrm{L}^{-1}$. De acordo com as concentrações de nutrientes, os padrões de alteração do xilema e da lignificação do caule foram diferentes, o que está de acordo com os resultados dos estudos fisiológicos realizados sobre os efeitos da aplicação de nanopartículas de sílica e cálcio em soluções nutritivas. Sob a epiderme, havia uma hipoderme (esclerênquima) que fortalece o tecido do caule. Nanopartículas de sílica e quelato de cálcio decorrente do aumento do conteúdo de fenilalanina amonia-liase e seu efeito nos ciclos de produção de celulose e lignina e ao aumento do esclerênquima do caule, levaram à resistência e lignificação da haste, o que acabou diminuindo a curvatura do caule. De acordo com os resultados do estudo, a aplicação de $40 \mathrm{mg} \mathrm{L}^{-1}$ de Nanopartícula-SiO $\mathrm{e}_{2} 60 \mathrm{mg} \mathrm{L}^{-1}$ de quelato de Ca em solução nutritiva hidropônica é recomendada para o cultivo de flores de gérbera.

Palavras-chave: anatomia; celulose; hidroponia; lignina; enzima fenilalanina amonia-liase.

*Corresponding author: dr.tofighi.alikhani@gmail.com

https://doi.org/10.1590/2447-536X.v27i3.2308

Received: Nov 18, 2020 | Accepted: Feb 19, 2021 | Available online: June 17, 2021

Licensed by CC BY 4.0 (https://creativecommons.org/licenses/by/4.0/)

Area Editor: Gláucia Moraes Dias 


\section{Introduction}

Gerbera is a perennial and ornamental genus of plants in the Asteraceae which consists of about 30 species (Park et al., 2017). Around the world, gerbera is grown as a cut flower and is considered one of the top 10 cut flowers worldwide. The commercial value of this flower has an increasing trend; for example, in 2019, its value was 234 million dollars and 85 million branches were sold just in USA. In addition to its value as cut-flower, this ornamental flower is also sold as pot-plant (Park et al., 2017; Murthy and Subbaiah, 2020). Despite their popularity, gerberas are afflicted with bent necks as the most important postharvest disorder and therefore have a short vase life (Aghdam et al., 2019). Lasting longevity of gerberas after harvest is affected by two important factors, i.e., wilting of flowerets and bending of flowering stems. Water balance is one of the important factors that control flower quality and determine cut flower longevity, as these characteristics are highly affected by the balance between water absorption and loss (Da Silva, 2020); so, every factor that destroys this balance, plays a crucial role in flower senescence and wilting. After placing the cut flowers in water, due to the occlusion of xylem over time, water intake becomes harder (Van Doorn, 1997). Normally, there are two types of occlusion in vessels. Physical occlusion of xylem vessel, which is due to the formation of air bubbles, accumulation of small bacterial particles or bacterial secretion at the end of the stem. This kind of occlusion can be cured by cutting the end of stems (Van Doorn and Vaslier, 2002). The other type of occlusion is due to physiological processes which start from the bottom of stems and moves toward their top. This is due to the synthesis of phenolic compounds such as subrin and lignin in xylem and the activity of oxidative enzymes in plant wounds. Synthesis of these compounds is a quick response to the wound (first 12 hours) which heals and closes the wound. Completion of this process leads to water deficiency (Loubaud and Van Doorn, 2004; Van Doorn and Vaslier, 2002). Presence of macromolecules like phenyl-propanoid is known as one of the important pathways in producing secondary plant metabolites that end in the production of various phenolic compounds such as lignin, phenolic acids, and flavonoids which play important structural and defensive roles (Hatfield and Vermerris, 2001); in other words, lignin synthesis is composed of monolinguals including alcohols like p-coumaryl, coniferyl, and sinapyl and their transfer to cell wall and eventually their polymerization are affected by the catalytic activity of many enzymes such as phenylalanine ammonia-lyase (PAL), peroxidase (POD), cinnamyl alcohol dehydrogenase (CAD), etc. (Hatfield and Vermerris, 2001; Ralph et al., 2004). Researchers suggest various strategies for increasing flower longevity, including the addition of different compounds to the vase container. Among them, silica and calcium are applied as two important nutrients for keeping flower persistent. Silicium, that is $\mathrm{SiO}_{2}$ (Silicium Dioxide or Silica), is the second most abundant element in the Earth's crust (Epstein, 1994). This element is useful for flower persistence in plants (Ma et al., 2001). Plants grown without silica are weaker and show abnormal growth and differentiation (Wang et al., 2017). Appropriate application of this nutrient can increase plant compatibility and disease tolerance, decrease nutrient deficiencies, improve product quality and, ultimately, increase crop yields (Ma et al., 2001; Snyder et al., 2016). After the absorption of silica, it moves through xylem in plant and transfers to branches due to transpiration (Ma and Takahashi, 2002). Effective application of silica to reduce stem bending in cut flowers has been observed in several researches (El-Serafy, 2019; Aghdam et al., 2019). It seems that applying nutrients with higher absorptivity in soilless cultures is significantly important in improving crop products; nanonutrients are among these absorbable nutrients. Nanostructured material is called to the material with at least one dimension smaller than $100 \mathrm{~nm}$. Nanomaterials have attractive characteristics such as being small, light, and multifunctional, small amounts of them are needed and help in saving consumable materials (Alinejad and Goli, 2005; Tavan et al., 2014). In addition to use of nano-fertilizers in controlling nutrient release, they can also be used for improving plant qualitative and quantitative yields of plants and be considered as an effective step to gain environment-friendly and sustainable agriculture (Mahajan et al., 2011). Recently, several good efforts have been made in order to apply nano-fertilizers for plant growth (Rane et al ,.2015; Liu et al., 2016; Mohammadi et al., 2019; 2020). Probably, using silica in the form of nanoparticles causes higher reactivity and absorptivity and satisfies plant needs more effectively. Also, calcium is a macronutrient and an important component of plant cell wall and plays an important role in the structure of cell wall and cell membrane (Hepler and Wayne, 1985). Calcium is an immobile nutrient in phloem and its transfer occurs through xylem (Barker and Pilbeam, 2007). Generally, calcium moves through the apo plastic pathway and its movement in xylem with retransfer ability is limited; thus, its concentration in organs with low transpiration like flowers (in which, nutrition is mostly through phloem) is low (Hepler, 2005). On the other hand, low transpiration leads to the risk of lowering calcium concentration in tissues under the critical level; therefore, side effects of calcium deficiency can be largely seen in organs with low transpiration, including flowers (Hepler and Wayne, 1985; Hepler, 2005). Results of several studies on gerberas (Park et al., 2017), gladiolus (Pruthi et al., 2001), chrysanthemum, and tagetes (Patel and Mankad, 2002) have illustrated that calcium is able to decrease stem bending in gerberas. Untill now, there were no studies on the combined application of Silica Nanoparticles and Calcium Chelate and their effects on decreasing stem bending in gerbera flowers. Therefore, the present research was aimed to study the effects of Silica Nanoparticles (Nanoparticle-SiO ${ }_{2}$ ) and Calcium Chelate (Ca-Chelate) on some morphophysiological and histological characteristics of gerbera stem under hydroponic culture in order to determine the optimal concentrations of Nanoparticle- $\mathrm{SiO}_{2}$ and $\mathrm{Ca}-\mathrm{Chelate}$ in nutrient solution for improving plant yield (both quantitatively and qualitatively), including decreasing stem bending. 


\section{Materials and Methods}

Factorial experiment, in the form of completely randomized design with two factors, was conducted in four replicates at the hydroponic greenhouse of Shahed University during 2019 and 2020. The first factor was nanoparticle- $\mathrm{SiO}_{2}$ concentration in nutrient solution at 4 levels $\left(0,20,40\right.$, and $\left.80 \mathrm{mg} \mathrm{L}^{-1}\right)$ from the source material $\mathrm{SiO}_{2}$, and the second factor was calcium concentration in nutrient solution at 4 levels $\left(0,60,120\right.$, and $\left.240 \mathrm{mg} \mathrm{L}^{-1}\right)$ from the source material calcium chelate (Ca-EDTA). The greenhouse is located at $31^{\circ} 36^{\prime} \mathrm{N}$ and $48^{\circ} 53^{\prime} \mathrm{E}$. It is $1,050 \mathrm{~m}$ above sea level and has a mean precipitation of $216 \mathrm{~mm}$. The day and night temperatures in the greenhouse were $20-25$ and $13-16^{\circ} \mathrm{C}$, respectively, with light intensity of $500-600 \mu \mathrm{mol} \mathrm{m} \mathrm{m}^{-2} \mathrm{~s}^{-1}$. Moreover, the humidity in the greenhouse was adjusted to $60-70 \%$ using a humidity controller (pressure fogging system). In this experiment, the plant material used was the gerbera cultivar Stanza (a modified cultivar), and the farming in the greenhouse was done as usual.

Preparation of seedbed and nutrient solutions for hydroponic cultivation

To fill the 4-liter pots, the perlite and peat moss pot media were used at the ratio of 50:50\% (V/V). Transplants of 3-4 leaves obtained from the tissue culture of gerbera cultivar Stanza were cultivated individually in the 4-liter plastic pots placed on the 1-m-high platforms. The pots were placed in one row with a spacing of $40 \times 40 \mathrm{~cm}$. Hoagland formula (Hoagland and Arnon, 1950), proposed by Agricultural Research Center of California State, USA, was used to treat the pots with the basic nutrient solution. Concentrations of Hoagland nutrient solution (before and after modifications) are presented in Table 1. Silicium dioxide $\left(\mathrm{SiO}_{2}\right)$, purchased from Tecnan Co. England, was used to prepare a solution containing different concentrations of silica nanoparticles. To prepare solutions of $0,20,40$,

Table 1. Nutrient concentration in Hoagland's solution.

\begin{tabular}{|l|c|c|c|}
\hline $\begin{array}{l}\text { Nutrient } \\
\text { element }\end{array}$ & $\begin{array}{c}\text { Chemical } \\
\text { formula }\end{array}$ & $\begin{array}{c}\mid c \\
\text { (mefore } \\
\text { modifications }\end{array}$ & $\begin{array}{c}\text { After } \\
\text { modifications }\end{array}$ \\
\hline Nitrogen & ${\mathrm{N}-\mathrm{NO}_{3}}^{-1}$ Content & 200 & 242 \\
\hline Phosphorous & $\mathrm{P}$ & 60 & 31 \\
\hline Potassium & $\mathrm{K}$ & 300 & 232 \\
\hline Calcium & $\mathrm{Ca}$ & 170 & 224 \\
\hline Magnesium & $\mathrm{Mg}$ & 50 & 49 \\
\hline Sulfur & $\mathrm{S}$ & 33 & 113 \\
\hline Boron & $\mathrm{B}$ & 1.5 & 0.45 \\
\hline Copper & $\mathrm{Cu}$ & 0.1 & 0.02 \\
\hline Iron & $\mathrm{Fe}$ & 12 & 3 \\
\hline Manganese & $\mathrm{Mn}$ & 2 & 0.50 \\
\hline Molybdenum & $\mathrm{Mo}$ & 0.1 & 0.0106 \\
\hline Zinc & $\mathrm{Zn}$ & 3 & 0.48 \\
\hline
\end{tabular}

and $80 \mathrm{mg} \mathrm{L}^{-1}$ silica nanoparticles, $0,1.2,2.4$, and $3.6 \mathrm{~g}$ of silica nanoparticles were weighed, respectively. Then, they were added to 100-liter barrels containing nutrient solution and distilled water with a ratio of 1:100 (V/V). Moreover, the calcium chelated with EDTA from BASF Co. England, which contained $9.5 \%$ pure calcium, was used to prepare the solutions with various calcium concentrations. To make solutions with $0,60,120$, and $240 \mathrm{mg} \mathrm{L}^{-1}$ calcium chelate, $0,37.8,75.7$, and $151.8 \mathrm{~g}$ of calcium chelate were weighed, respectively. Then, they were added to 100-liter barrels containing nutrient solution and distilled water with a ratio of $1: 100(\mathrm{~V} / \mathrm{V})$.

The hydroponic system used in this experiment was the application of an open solution; the nutrients were transferred through dropping tubes from the nutrient repository with a capacity of $4 \mathrm{~L} \mathrm{hr}^{-1}$ to the pots with a capacity of $400 \mathrm{ml}$. The solution was added to all the pots twice a day in a certain time, each time for nearly $4 \mathrm{~m}$ (i.e. $0.53 \mathrm{~L})$. This process was performed using an adjusted digital timer. Furthermore, to prevent accumulation of salts and salinity stress in the cultivation bed, the plant root zone was washed with distilled water every week. The nutrient solution $\mathrm{pH}$ and EC were 6 and 2-2.1 dS m $\mathrm{d}^{-1}$, respectively.

\section{Measurement of plant morphological and physiological characteristics}

After three months of plant treatment, the flowers were harvested and then the flowering stem bending (deviation from $90^{\circ}$ ) was measured using a goniometer. The stem lignin percentage was measured according to the T222 cm-88 standard using the TAPPI procedure (Tappi, 1992). Cellulose content was measured using the method proposed by Browning (1967). For the measurement of the activity of phenylalanine ammonia-lyase in leaf, the method suggested by Saunders and McClure (1974) was followed.

Data analysis was done using SPSS 9.1 software, and comparison of means was done using the Duncan's multiple range test at $5 \%$.

\section{Histological study of gerbera histology stem}

Since bending is observed in the upper parts of the stem in most plants, the cutting of samples in this study was done manually using a blade under the optical microscope of anatomy (samples were cut transversely from the $10 \mathrm{~cm}$ area beneath the flower). Then, using fixative (to destroy cells without changing the nature and paint ability), samples were transferred to a solution of $850 \mathrm{~mL} 70 \%$ ethanol,

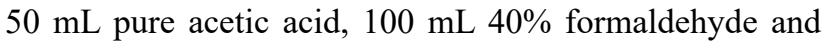
in order to let the compounds in the tissues, the samples remained in the solution for 10 days. After fixing the samples, tissue cuts were sliced using a microtome. Next, the Safranin staining method was applied to the intended tissues (Cutler et al., 2007). The stained slices were places on microscope slides and lamella were placed on them; these slides were observed under an optical microscope (FLUO-3 model, BEL engineering S.R.L, Italy) with 55×, $65 \times$, and $75 \times$ magnification and microscope images were shot using a camera (model: Eurekam 5.0, resolution: $5 \mathrm{M}$ pixel, 2.0 USB; BEL engineering S.R.L, Italy). 


\section{Results}

The effects of treatments on morphological and physiological properties of gerbera

\section{Stem bending}

According to Table 2, the highest stem bending (12.35 deviation from $90^{\circ}$ ) belonged to the control. The lowest stem bending ( 8.16 deviation from $\left.90^{\circ}\right)$ was observed in the treatment with $40 \mathrm{mg} \mathrm{L}^{-1}$ Nanoparticle- $\mathrm{SiO}_{2}$ and 240 mg $\mathrm{L}^{-1} \mathrm{Ca}-\mathrm{Chelate}$. The increase in Nanoparticle-SiO application resulted in lower stem bending, such that, compared to the control, applying 20,40 , and $80 \mathrm{mg} \mathrm{L}^{-1}$ Nanoparticle- $\mathrm{SiO}_{2}$ decreased stem building by 10, 21, and $25 \%$, respectively. Furthermore, compared to the control, applying 60, 120, and $240 \mathrm{mg} \mathrm{L}^{-1} \mathrm{Ca}-$ Chelate without applying Nanoparticle- $\mathrm{SiO}_{2}$ decreased stem bending by 19 , 21 , and $28 \%$, respectively.

\section{Stem lignin content}

Results of the mean comparison indicated that adding higher amounts of $\mathrm{Ca}$-chelate without nanoparticle- $\mathrm{SiO}_{2}$ application increased the stem ash content. Applying 60,120 , and $240 \mathrm{mg} \mathrm{L}^{-1} \mathrm{Ca}$-chelate increased the stem lignin content by about 29, 30, and 35\%, respectively, compared to the control (Table 2). Among the different concentrations of silica nanoparticles (without $\mathrm{Ca}$-chelate application), the highest stem lignin content (14.6\%) was observed in the treatment with $40 \mathrm{mg} \mathrm{L}^{-1}$ nanoparticle$\mathrm{SiO}_{2}$. The treatment with $240 \mathrm{mg} \mathrm{L}^{-1} \mathrm{Ca}$-chelate without nanoparticle- $\mathrm{SiO}_{2}$ addition led to the highest stem lignin content $(16.5 \%)$.

\section{Cellulose content}

According to the mean comparison, the highest cellulose content (44.98) belonged to the treatment with $80 \mathrm{mg} \mathrm{L}^{-1}$ Nanoparticle- $\mathrm{SiO}_{2}$ and $60 \mathrm{mg} \mathrm{L}^{-1} \mathrm{Ca}-\mathrm{Chelate}$, which was not significantly different from the treatments with $80 \mathrm{mg} \mathrm{L}^{-1}$ Nanoparticle-SiO and 120 or $240 \mathrm{mg} \mathrm{L}^{-1} \mathrm{Ca}-\mathrm{Ch}$ late (Table 2). The lowest cellulose (39.01\%) content was observed in the control. Among the treatments containing only Nanoparticle$\mathrm{SiO}_{2}$ without any Ca-Chelate, the highest cellulose (43.11\%) content was obtained in the treatment containing $80 \mathrm{mg} \mathrm{L}^{-1}$ Nanoparticle- $\mathrm{SiO}_{2}$. In the absence of Nanoparticle-SiO $\mathrm{S}_{2}$, the increases in the application rate of Ca-Chelate led to lower Cellulose content, and the highest content of cellulose (41.10\%) was observed in the treatment with $60 \mathrm{mg} \mathrm{L}^{-1} \mathrm{Ca}-\mathrm{Chelate}$.

\section{Activity of phenylalanine ammonia-lyase enzyme}

According to Table 2, applying Nanoparticle- $\mathrm{SiO}_{2}$ and $\mathrm{Ca}-\mathrm{Chelate}$ increased the activity of phenylalanine ammonia-

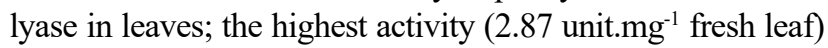
was observed in the treatment with $60 \mathrm{mg} \mathrm{L}^{-1} \mathrm{Ca}-\mathrm{Chelate}$ with no Nanoparticle-SiO $\mathrm{S}_{2}$ application, which was not significantly different with the treatment having $20 \mathrm{mg} \mathrm{L}^{-1}$ Nanoparticle$\mathrm{SiO}_{2}$ without addition of Ca-Chelate. The lowest activity of phenylalanine ammonia-lyase in leaves ( 0.51 units per $\mathrm{mg}$ fresh leaf) belonged to the control. With the increasing application rate of Ca-Chelate (more than $60 \mathrm{mg} \mathrm{L}^{-1}$ ) without silica, and Nanoparticle- $\mathrm{SiO}_{2}$ (over $20 \mathrm{mg} \mathrm{L}^{-1}$ ) without CaChelate addition, there was a decreasing trend in the activity of this enzyme. In the combined treatments, the highest activity of phenylalanine ammonia-lyase in leaf (1.59 units per $\mathrm{mg}$ fresh leaf) was observed in the treatment with $80 \mathrm{mg}$ $\mathrm{L}^{-1}$ Nanoparticle-SiO ${ }_{2}$ and $240 \mathrm{mg} \mathrm{L}^{-1} \mathrm{Ca}-$ Chelate.

Table 2. Mean comparison of the effects of different concentrations of nanoparticle-SiO 2 and Ca-chelate on morphological and physiological characteristics of gerbera (Gerbera Jamesonii L.)*.

\begin{tabular}{|c|c|c|c|c|c|}
\hline \multicolumn{2}{|l|}{ Treatments $\left(\mathrm{mg} \mathrm{L}^{-1}\right)$} & \multirow{2}{*}{$\begin{array}{l}\text { Flowering stem } \\
\text { bending }(\text { deviation } \\
\left.\text { from } 90^{\circ}\right)\end{array}$} & \multirow{2}{*}{$\begin{array}{c}\text { Cellulose } \\
\text { content }(\%)\end{array}$} & \multirow{2}{*}{$\begin{array}{l}\text { Stem lignin } \\
\text { content }(\%)\end{array}$} & \multirow{2}{*}{$\begin{array}{l}\text { The activity of phenylalanine } \\
\text { ammonia-lyase enzyme in leaves } \\
\text { (unit per mg fresh leaf) }\end{array}$} \\
\hline Nanoparticle-SiO & Ca-Chelate & & & & \\
\hline \multirow{4}{*}{0} & 0 & $12.35 \mathrm{a}$ & $39.01 \mathrm{i}$ & $12.21 \mathrm{~g}$ & $0.51 \mathrm{~g}$ \\
\hline & 60 & $10.02 \mathrm{bcd}$ & 41.10 ef & $15.75 \mathrm{abc}$ & $2.87 \mathrm{a}$ \\
\hline & 120 & $9.75 \mathrm{bcd}$ & $40.72 \mathrm{efg}$ & $15.89 \mathrm{abc}$ & $2.19 \mathrm{~b}$ \\
\hline & 240 & $8.89 \mathrm{de}$ & $39.89 \mathrm{gh}$ & $16.57 \mathrm{a}$ & $1.68 \mathrm{c}$ \\
\hline \multirow{4}{*}{20} & 0 & $11.07 \mathrm{~b}$ & $40.76 \mathrm{efg}$ & 14.34 cdef & $2.93 \mathrm{a}$ \\
\hline & 60 & $10.17 \mathrm{bcd}$ & $41.52 \mathrm{de}$ & 15.53 abcde & $0.74 \mathrm{f}$ \\
\hline & 120 & $9.77 \mathrm{bcd}$ & $42.69 \mathrm{bc}$ & 15.05 abcde & $0.95 \mathrm{f}$ \\
\hline & 240 & $8.78 \mathrm{de}$ & $42.73 \mathrm{bc}$ & $14.25 \mathrm{def}$ & $1.37 \mathrm{~cd}$ \\
\hline \multirow{4}{*}{40} & 0 & $9.78 \mathrm{bcd}$ & $42.37 \mathrm{~cd}$ & 14.6 bcdef & $1.58 \mathrm{~cd}$ \\
\hline & 60 & $11.15 \mathrm{~b}$ & $40.27 \mathrm{fgh}$ & $14.25 \mathrm{def}$ & $0.88 \mathrm{f}$ \\
\hline & 120 & $8.9 \mathrm{de}$ & $41.52 \mathrm{de}$ & 15.51 abcde & 0.98 ef \\
\hline & 240 & 8.16 ef & 41.33 ef & 15.52 abcde & $1.41 \mathrm{~cd}$ \\
\hline \multirow{4}{*}{80} & 0 & $9.2 \mathrm{de}$ & $43.11 \mathrm{bc}$ & 14.41 ef & $1.46 \mathrm{~cd}$ \\
\hline & 60 & $11.39 \mathrm{~b}$ & $44.98 \mathrm{a}$ & $14.00 \mathrm{ab}$ & $1.33 \mathrm{de}$ \\
\hline & 120 & $10.91 \mathrm{bc}$ & $44.05 \mathrm{a}$ & $16.04 \mathrm{ab}$ & $1.34 \mathrm{~d}$ \\
\hline & 240 & $9.78 \mathrm{bcd}$ & $44.13 \mathrm{a}$ & $16.25 \mathrm{ab}$ & $1.59 \mathrm{~cd}$ \\
\hline
\end{tabular}

*In columns, the treatments followed by similar letters are not statistically different at $95 \%$ confidence level (Duncan test). 

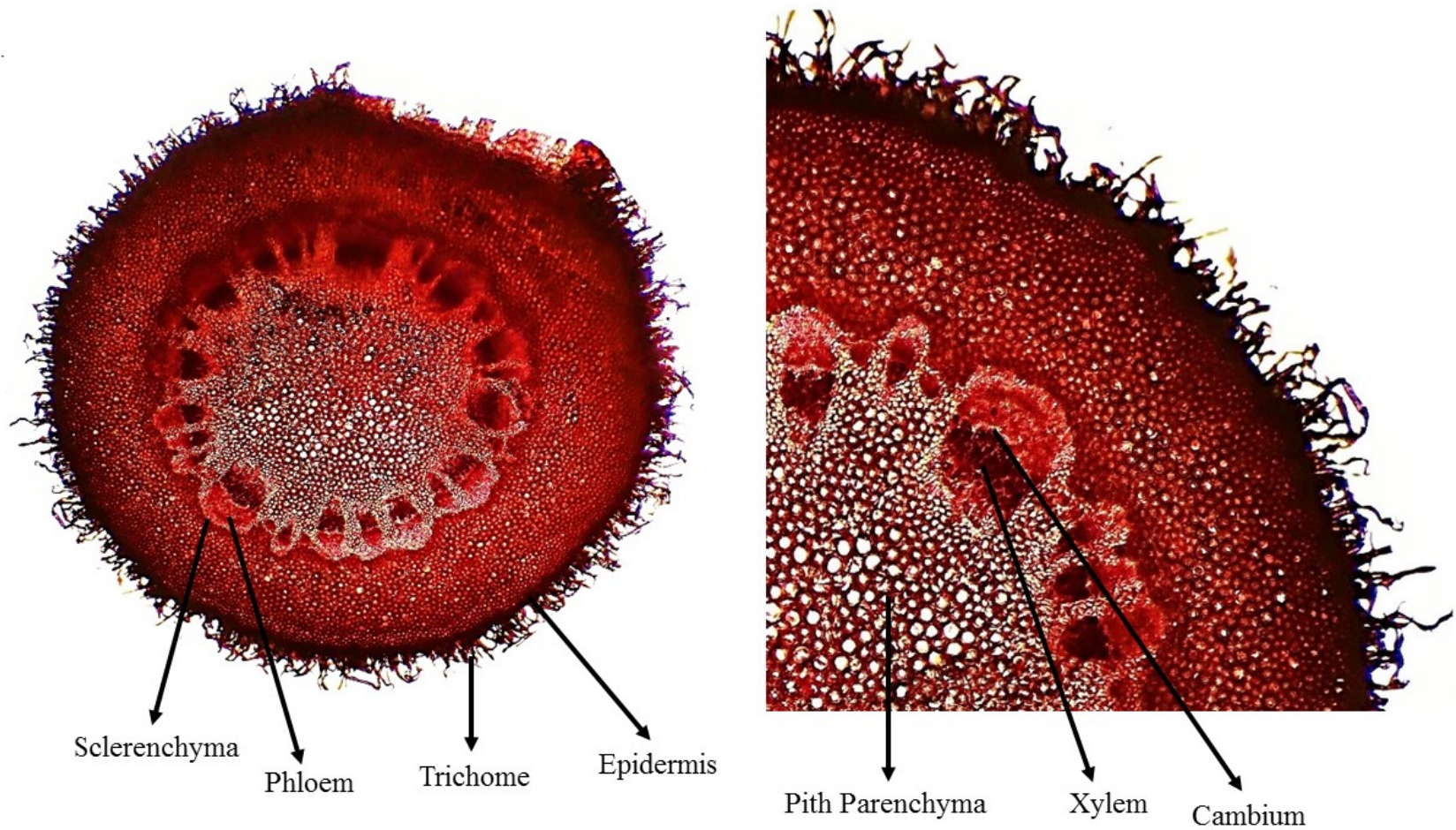

Figure 1. Cross section of gerbera's flowering stem with magnification of $75 \times$.

Effect of study factors on the histology of gerbera's stem

In Figure 1, the cross-section of gerbera's flowering stem with $75 \times$ magnification indicated that the cross section of young stem at bend (near the point stem joints flower) was circular; in addition, the anatomical specifications that could be seen in the cross section include: epidermis is consisted of round cells, that many of these cells are differentiated to trichome, and that these trichomes are in the form of straight glands. Under the epidermis, there is the hypodermis, which strengthens stem tissue (hypodermis can be as collenchyma or sclerenchyma; in the case of sclerenchyma, which is the case of this study, hypodermis turns into a wooden layer and enhances plant strength). Xylem and phloem vascular bundles are placed all around the stem. Xylem vessels were placed near each other. Xylems near the cambium layer in the central cylinder of the stem have small cells and the vascular bundles beneath them were larger; again, the bundles near the pith were smaller. Also, the distance between xylem vascular bundles was filled with sparse cells of xylem parenchyma. Phloem vascular bundles were clearly observed between sclerenchyma and cambium. Vascular cambium was observed between xylem and phloem bundles and, also, pith parenchyma formed a large part of the central cylinder of stem.

Figure 2 indicates the effect of different concentrations of Nanoparticle- $\mathrm{SiO}_{2}$ and calcium on the anatomical characteristics, specially changes in the wooden parts of gerbera's flowering stems; in the presence of different factors, the pattern of changes in xylem and the rate of stem lignification are different according to nutrient concentration; this is in compliance with the physiological studies conducted on the effects of nanosilica and calcium concentrations in nutrient solution.

Figure 3 indicates the cross section of gerbera's flowering stems in the presence of $\mathrm{A}$ and $\mathrm{B}$ factors ( $\mathrm{A}$ and $\mathrm{B}$ are the combined factors of $\mathrm{Si}_{0} \mathrm{Ca}_{60}$ and $\mathrm{Si}_{20} \mathrm{Ca}_{120} \mathrm{mg} \mathrm{L}^{-1}$, respectively); The highest and lowest changes in the xylem and the amount of stem lignification in hypoderm and fiber along the vascular system are observed with factors A and $\mathrm{B}$, respectively.

The results indicated that applying Nanoparticle- $\mathrm{SiO}_{2}$ and $\mathrm{Ca}-\mathrm{Ch}$ late enhanced the amount of stem lignification and the fiber along the vessels of gerbera's flowering stems (Figure 3).

\section{DISCUSSION}

Cut flowers are among the gravity-sensitive flowers; during the maintenance of cut flowers, the stem bends in response to gravity and blocks the water pathway to the buds and semi-open flowers, thus accelerating their wilting. Recent researches on gerberas indicated that many factors are involved in stem bending, especially the inadequacy of sclerenchyma in the upper part of the stem. Sclerenchyma and xylem have high contents of lignin and cellulose in their cells (Perik et al., 2012). The roles of plant vessels blockage and water transfer in gerbera longevity post-harvest were studied (Li et al., 2009). Perik et al. (2012) studied the reasons behind the bending of flowering stems in gerberas and illustrated that lack of sclerenchyma development and lack of lignin formation in stem are among the main reasons of stem bending. Furthermore, it is reported that preventing the activity of phenylalanine ammonia-lyase in gerberas increased stem bending (Ferrante et al., 2007). 

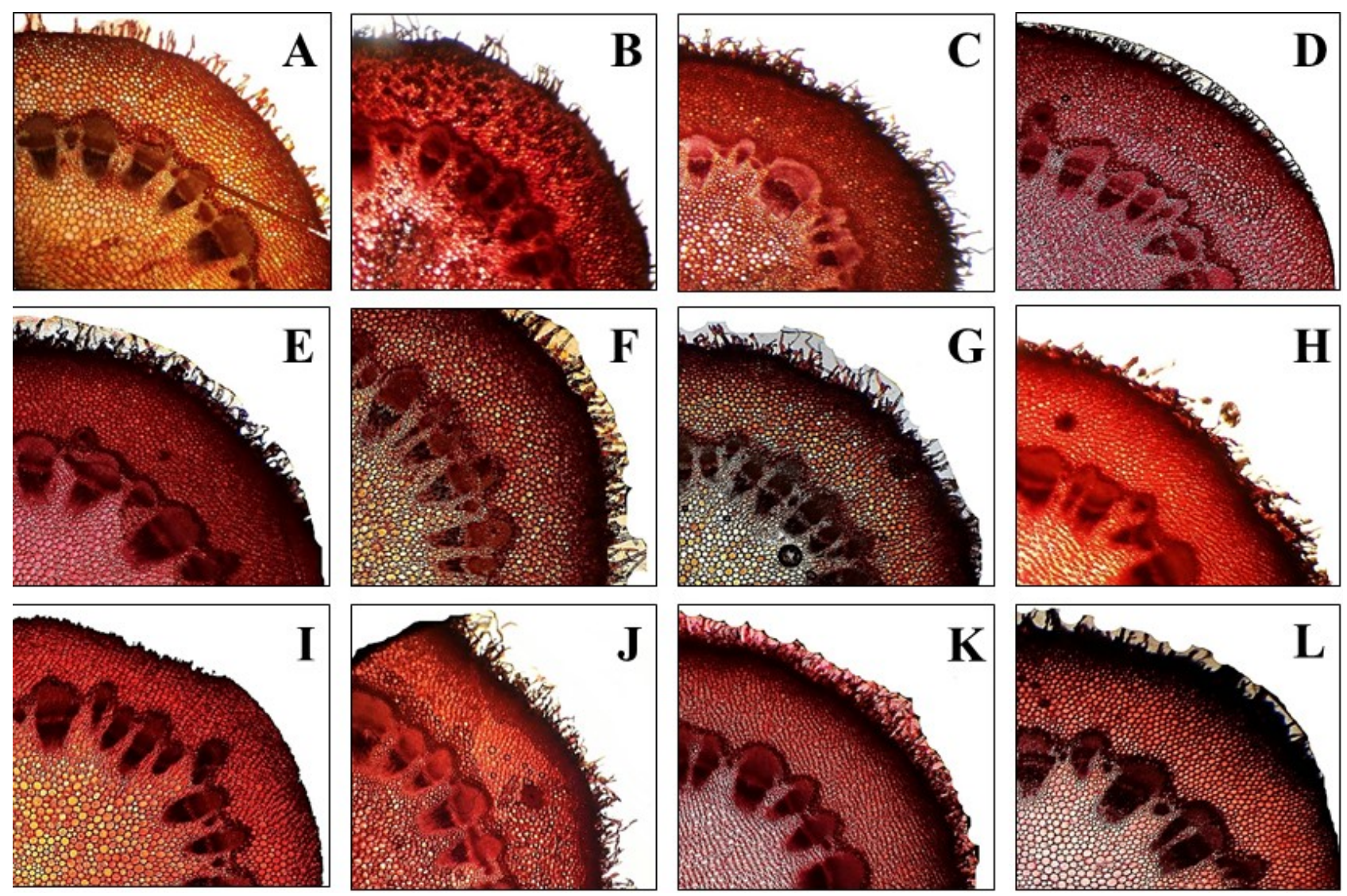

Figure 2. The effect of different concentrations of nanosilica and calcium on the anatomical characteristics, especially changes in the lignified parts of gerbera's flowering stem (Gerbera Jamesonii L.) with different factors. Cross sections are represented with magnification of $75 \times\left(\mathrm{A}, \mathrm{B}\right.$, and $\mathrm{C}$ indicate $\mathrm{Si}_{0} \mathrm{Ca}_{60}, \mathrm{Si}_{0} \mathrm{Ca}_{120}$, and $\mathrm{Si}_{0} \mathrm{Ca}_{240} \mathrm{mg} \mathrm{L}^{-1}$, respectively. $\mathrm{D}, \mathrm{E}$, and $\mathrm{F}$ indicate $\mathrm{Si}_{20} \mathrm{Ca}_{60}, \mathrm{Si}_{20} \mathrm{Ca}_{120}$, and $\mathrm{Si}_{20} \mathrm{Ca}_{240} \mathrm{mg} \mathrm{L} \mathrm{L}^{-1}$, respectively. $\mathrm{G}, \mathrm{H}$, and $\mathrm{I}$ indicate $\mathrm{Si}_{40} \mathrm{Ca}_{60}, \mathrm{Si}_{40} \mathrm{Ca}_{120}$, and $\mathrm{Si}_{40} \mathrm{Ca}_{240} \mathrm{mg} \mathrm{L}$, respectively. $\mathrm{J}, \mathrm{K}$, and $\mathrm{L}$ indicate $\mathrm{Si}_{80} \mathrm{Ca}_{60}, \mathrm{Si}_{80} \mathrm{Ca}_{120}$, and $\mathrm{Si}_{80} \mathrm{Ca}_{240} \mathrm{mg} \mathrm{L}^{-1}$, respectively).

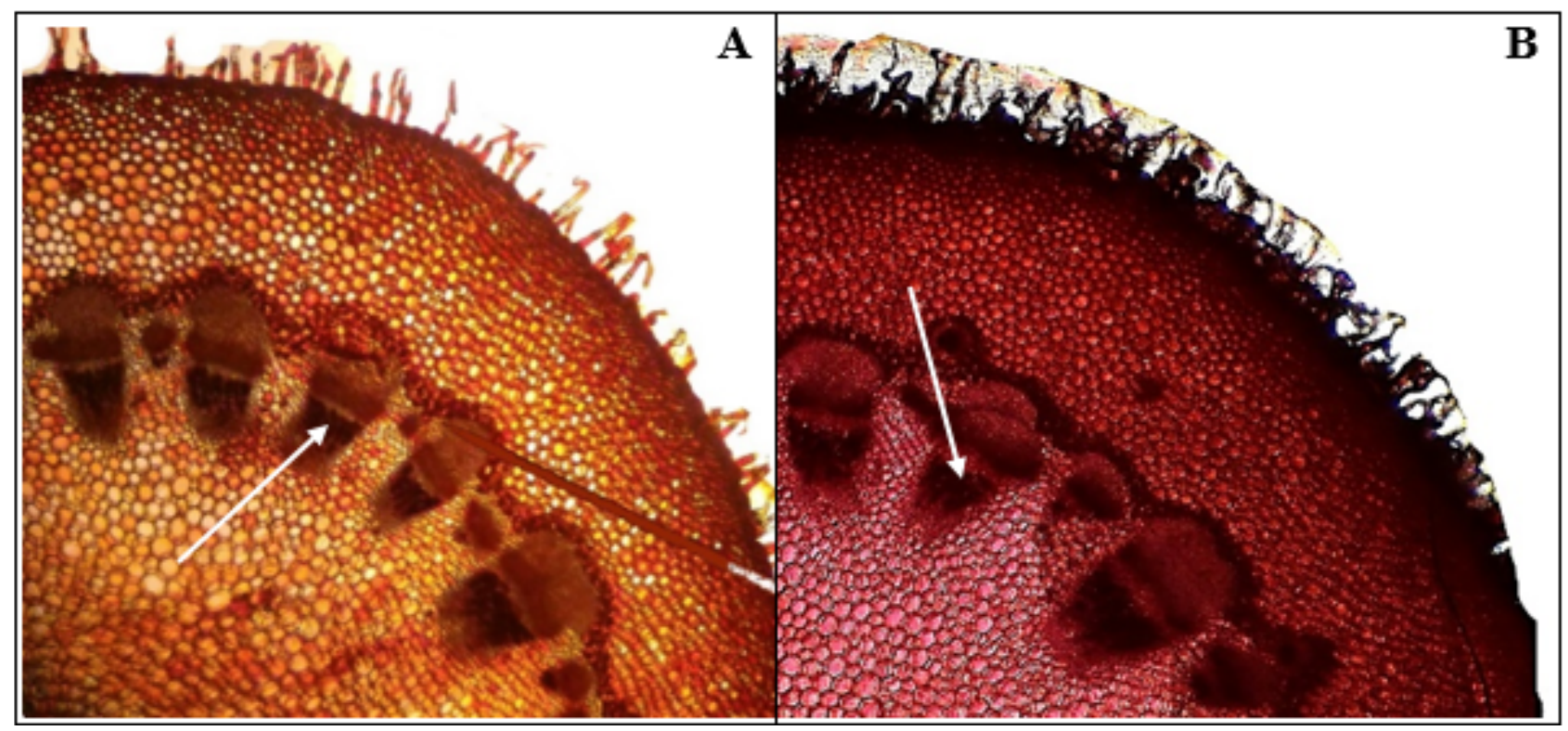

Figure 3. The cross section of the flowering stem of gerbera with $\mathrm{A}$ and $\mathrm{B}$ factors. Cross sections are represented with magnification of $75 \times$ (A and $\mathrm{B}$ indicate $\mathrm{Si}_{0} \mathrm{Ca}_{60}$ and $\mathrm{Si}_{20} \mathrm{Ca}_{120}$, respectively). Areas pointed by white arrows indicate the changes of xylem and the amount of stem lignification (becoming woody) in hypodermis and the fiber along the vessels of a gerbera's flowering stem. 
Our results indicated that both study factors, i.e., applying Nanoparticle-SiO $\mathrm{S}_{2}$ and $\mathrm{Ca}-\mathrm{Ch}$ late, enhanced the activity of phenylalanine ammonia-lyase and improved sclerenchyma in gerbera stems, thus decreasing stem bending in gerbera cut flowers. In agreement with the reports of Javad et al. (2015), the findings of this study indicated that applying Nanoparticle-SiO2 and Ca-Chelate were two important factors affecting the lignin formation and stem bending disorder of gerbera cut flowers. Javad et al. (2011) reported that phenylalanine ammonialyase enzyme is among the effective factors for lignin production cycle and, therefore, increasing stem strength in gerberas. A possible reason of higher PAL activity (which is the most important enzyme in the phenylpropanoid cycle) due to Si can be due to positive effects of Si on plant resistance, which is the result of increasing antioxidant power and capacity. This is in line with the results of Edrisi et al. (2019) and Ranjbar et al. (2017) in gerberas indicating the positive effect of silicon on the activities of antioxidant enzymes, including catalase, peroxidase, and superoxide dismutase. Additionally, calcium is significantly effective in some of the plants' physiological processes, like enzymatic activities. Free radicals are composites or free and unpaired unstable electrons, and calcium, as a cation, can provide the positive charges needed to neutralize free radicals, reduce the negative effects of free radicals, and contribute to cell antioxidant activity (Jiang and Huang, 2001). Our results matched up well with the findings by Siddiqui et al. (2012) who reported an increase $24 \%$ in the activities of antioxidant enzymes (catalase) as a result of calcium application (20 ppm). Calcium serves as a secondary messenger of environmental stimuli and stimulates pseudo calmodulin proteins reacting to calcium. The changes in the structure of calmodulin proteins, as a result of binding with calcium ions, provide a series of mechanisms, for instance, ion transport, gene expression, cell motility, cell growth, cell proliferation, and its stress resistance through activating antioxidant systems (Jiang and Huang, 2001). Therefore, plant resistance to environmental stress, like stem bending, could be improved by applying appropriate amounts of calcium.

Other researches showed that compared to control, the joint application of Nanoparticle- $\mathrm{SiO}_{2}$ and $\mathrm{Ca}-$ Chelate increased cellulose content significantly and also the joint application decreased stem bending and increased sclerenchyma in stems (Table 2). In fact, silica precipitates on cell walls and increases the synthesis of phenolic compounds and lignin and their precipitation on cell wall. Cell wall strength in account of silica might be attributed to the biosynthesis of phenolic compounds (Zhang et al., 2013). Plant cell wall is composed of polysaccharides, such as cellulose, pectin, and hemicellulose. Silica significantly increases cellulose, hemicellulose, and finally lignin content. In the cell wall, silica serves as a ring between lignin and carbohydrates. Therefore, utilizing silica creates more lignin-carbohydrate complexes on epidermal cell walls. Thus, in addition to $\mathrm{Si}$ precipitation on lignified cell walls, silica influences plant stem bending through regulating lignification (LI et al., 2012). Nazaralian et al. (2017) suggested that silica was effective in lignification, creating cellulose, hemicellulose, and antioxidant enzymes. Additionally, calcium accumulation in plant tissues enhances a polymeric connection between middle blades of pectocellulose membrane strengthening cell wall network and result in higher mechanical strengths of tissues and less stem bending (Gerasopoulos and Chebli, 1999).

In fact, Nanoparticle- $\mathrm{SiO}_{2}$ and $\mathrm{Ca}-\mathrm{Chelate} \mathrm{by} \mathrm{increasing}$ the activity of PAL and its effect on the production of cellulose and lignin and improving sclerenchyma in the stems increase stem strengths and lignifies it, which eventually reduces stem bending. Aghdam et al. (2019) studied the effect of calcium on stem bending in two gerbera cultivars (i.e., Intense and Rosaline) which were resistant and sensitive to stem bending, respectively. The results demonstrated that calcium application increased lignin, cellulose, and hemicellulose contents in both cultivars, compared to control. Alian et al. (2016) indicated that both their study factors, i.e., sodium silicate and silica nanoparticles, thickened the xylem cell wall in the stems and roots of fenugreek. Furthermore, silica increased root diameter and lignin content at the first stages of germination in canola (Kuai et al., 2017). Lv et al. (2011) in a study on the anatomy and physiology of the receptacle in the flowering stem of chrysanthemums cut flower reported that compared to the varieties with low longevity, the varieties with high longevity contain higher contents of vascular nutrients, lignin, and water; this is in line with our findings about the importance of lignin as a medium for water transfer through stem and also its role in plant strength and therefore, improving flower longevity and decreasing stem bending.

\section{Conclusion}

In general, appropriate nutrient solution and optimal environmental conditions are important to ensure the optimum crop production. In this study, nanoparticle$\mathrm{SiO}_{2}$ and $\mathrm{Ca}$-chelate were applied in the nutrient solution of gerbera. The results indicated that silica nanoparticles and calcium chelate due to their effect in increasing the amount of phenylalanine ammonia-lyase and the effects of this enzyme in the production cycles of cellulose and lignin and increasing sclerenchyma in stems, would lead to stem reinforcement and lignification which, in turn, decreases stem bending. It should be noted that combined treatments of Nanoparticle $\mathrm{SiO}_{2}$ and $\mathrm{Ca}-\mathrm{Ch}$ late were more effective than their individual applications. Our findings suggested that the application of $40 \mathrm{mg}$ $\mathrm{L}^{-1}$ Nanoparticle-SiO $\mathrm{Si}_{2}$ and $60 \mathrm{mg} \mathrm{L}^{-1} \mathrm{Ca}-\mathrm{Chelate}$ were the most effective treatments in hydroponic nutrient solutions for the cultivation of gerbera.

\section{Author Contribution}

TTA:Conceptualization,DataCuration,FormalAnalysis, Writing — Original Draft. SJT: Supervision, Writing - 
Review \& Editing. AMT: Supervision, Writing - Review \& Editing. DT: Supervision, Writing — Review \& Editing.

\section{Acknowledgments}

The authors would like to express their gratitude to Dr. Mohammad Hossein Fotokian from Faculty of Agriculture, Shahed University for statistical analysis and Dr. Ahmad Asgharzadeh from Soil and Water Research Institute for providing the facilities for conducting the experiment.

\section{References}

AGHDAM, M.; ASIL, M.H.; GHASEMNEZHAD, M.; MIRKALAEI, S. A. A. M. Effects of pre-harvest applications of different source of calcium on the cell wall fractions and stem bending disorder of Gerbera (Gerbera jamesonii L.) cultivar flowers. Advances in Horticultural Science, v.33, n.1, p.57-65, 2019. https://doi.org/10.13128/ahs-23328

ALIAN, S.; AYRIAN, S.; GHARAMANI NEJAD, F.; NAJAFI, F.; GARGAR, M. Effect of silica and silica nanoparticles on the germination and growth of Fenugreek (Trigonella foenum-graecum L.). Journal of Developmental Biology, v.8, n.3, p.53-62, 2016.

ALINEJAD, D.; GOLI, E. Nanocomposites and their applications. Tehran: Tasvir Zaban, 2005.

Barker, A. V.; Pilbeam, D. J. Silicon. Handbook of plant nutrition, CRC, Elsevier, (Ed. 2), 2007.

CUTLER, D.F.; BOTHA, C.E.J.; STEVENSON, D.W. Plant anatomy: an applied approach. Malden: Blackwell, 2007. 302p.

DA SILVA, D.P.C; DE OLIVEIRA PAIVA, P.D.; HERRERA, R.C.; PORTO, J.M.P.; DOS REIS, M.V.; PAIVA, R. Effectiveness of silicon sources for in vitro development of gerbera. Plant Cell, Tissue and Organ Culture, v.141, p.77-85, 2020.

EDRISI, B.; BABALAR, M.; NADERI, R. Effect of silicon and salicylic acid on lignin formation and antioxidant enzymes in gerbera flower. Iran Journal of Horticultural Science, v.50, n.1, p.77-89, 2019. https://doi.org/10.22059/ ijhs.2017.231392.1229

EL-SERAFY, R.S. Silica Nanoparticles Enhances PhysioBiochemical Characters and Postharvest Quality of Rosa hybrida L. Cut Flowers. Journal of Horticultural Research, v.27, n.1, p.47-54, 2019. https://doi.org/10.2478/johr-2019-0006

EPSTEIN, E. The anomaly of silicon in plant biology. Proceedings of the National Academy of Sciences, v.91, n.1,p.11-17, 1994. https://doi.org/10.1073\%2Fpnas.91.1.11

FERRANTE, A.; ALBRICI, A.; ANTONACCI, S.; SERRA, G. Effect of promoter and inhibitors of phenyalanineammonia-lyase enzyme on stem bending of cut gerbera flower. Acta Horticulturae, v.755, p.471-476, 2007. https://doi.org/10.17660/ActaHortic.2007.755.64

GERASOPOULOS, D.; CHEBLI, B. Effects of preand postharvest calcium applications on the vase life of cut gerberas. Journal of Horticultural Science Biotechnology, v.74, n.1, p.78-81, 1999. https://doi.org/1 $0.1080 / 14620316.1999 .11511076$

HATFIELD, R.; VERMERRIS, W. Lignin Formation in Plants. The dilemma of linkage specificity. Plant Physiology, v.126, n.4, p.1351-1357, 2001. https://doi. org/10.1104\%2Fpp.126.4.1351

HEPLER, P.K. Calcium: a central regulator of plant growth and development. American Society Plant and Biology, v.17, n.8, p.2142-2155, 2005. https://doi. org/10.1105\%2Ftpc. 105.032508

HEPLER, P.K.; WAYNE, R.O. Calcium and plant development. Annual Review of Plant Physiology, v.36, n.1, p.397-439, 1985. https://doi.org/10.1146/annurev.pp.36.060185.002145

HOAGLAND, D.R.; ARNON, D.I. The water-culture method for growing plants without soil. Berkeley: California Agricultural Experiment Station, 1950. (Circular, v.347, n.2).

JAVAD, N.D.M.; AHMAD, K.; MOSTAFA, A.; ROYA, $\mathrm{K}$. Postharvest evaluation of vase-life, stem bending and screening of cultivars of cut gerbera (Gerbera jamesonii Bolus ex. Hook f.) flowers. African Journal of Biotechnology, v.10, n.4, p.560-566, 2011.

JAVAD, N.D.M.; AHMAD, K.; MOSTAFA, A.; ROYA, K.; HAMEDAN, J. Effect of postharvest pulse treatment of salicylic acid on phenylalanine ammonia-lyase activity (pal), lignin formation and stem bending disorder of gerbera cut flowers. Iranian Journal of Horticultural Sciences, v.46, n.2, p.279-290, 2015.

JIANG, Y.; HUANG, B. Effects of calcium on antioxidant activities and water relations associated with heat tolerance in two cool-season grasses. Journal of Experimental Botany, v.52, n.355, p.341-349, 2001.

KUAI, J.; SUN, Y.; GUO, C.; ZHAO, L.; ZUO, Q.; WU, J.; ZHOU, G. Root-applied silicon in the early bud stage increases the rapeseed yield and optimizes the mechanical harvesting characteristics. Journal of Field Crops Research, v.200, p.88-97, 2017. https://doi.org/10.1016/j.fcr.2016.10.007

LI, P.; SONG, A.; LI, Z.; FAN, F.; LIANG, Y. Silicon ameliorates manganese toxicity by regulating manganese transport and antioxidant reactions in rice (Oryza sativa L.). Plant and Soil, v.354, n.1-2, p.407-419, 2012. https:// doi.org/10.1007/s11104-011-1076-4

LI, X.; YANG, Y.; YAO, J.; CHEN, G.; LI, X.; ZHANG, Q.; WU, X. FLEXIBLE CULM 1 encoding a cinnamyl- 
alcohol dehydrogenase controls culm mechanical strength in rice. Plant Molecular Biology, v.69, n.6, p.685-697, 2009. https://doi.org/10.1007/s11103-008-9448-8

LIU, R.; ZHANG, H.; LAL, R. Effects of stabilized nanoparticles of copper, zinc, manganese, and iron oxides in low concentrations on lettuce (Lactuca sativa) seed germination: Nanotoxicants or nanonutrients? Water, Air, and Soil Pollution, v.227, n.1, p.42, 2016. https://doi. org/10.1007/s11270-015-2738-2

LOUBAUD, M.; VAN DOORN, W.G. Wound-induced and bacteria-induced xylem block age in Roses, Astilbe and Viburnum. Postharvest Biology and Technology, v.32, n.3, p.281-288, 2004. https://doi.org/10.1016/j. postharvbio.2003.12.004

LV, G.; TANG, D.; CHEN, F.; SUN, Y.; FANG, W.; GUAN, $\mathrm{Z}$; LIU, . The anatomy and physiology of spray cut chrysanthemum pedicels, and expression of a caffeic acid 3-O-methyltransferase homologue. Journal of Postharvest Biology and Technology, v.60, n.3, p.244-250, 2011. https://doi.org/10.1016/j.postharvbio.2011.01.004

MA, J.F.; MIYAKE, Y.; TAKAHASHI, E. Silicon as a beneficial element for crop plants. Studies in Plant Science, v.8, p.17-39, 2001. https://doi.org/10.1016/ S0928-3420(01)80006-9

MA, J.F.; TAKAHASHI, E. Soil, fertilizer, and plant silicon research in Japan. Kagawa: Elsevier, 2002. 281p.

MAHAJAN, P.; DHOKE, S.; KHANNA, A. Effect of nano-ZnO particle suspension on growth of mung (Vigna radiata) and gram (Cicer arietinum) seedlings using plant agar method. Journal of Nanotechnology, v.2011, 696535, 2011. https://doi.org/10.1155/2011/696535

MOHAMMADI, M.; TORKASHVAND, A.M.; BIPARVA, P.; ESFANDIARI, M. Synthesis ratios of Mg-Al and $\mathrm{Zn}-$ Al layered double hydroxides efficiency and selectivity in nitrate removal from solution. Global Journal of Environmental Science Management, v.5, n.4, p.485500, 2019. https://doi.org/10.22034/GJESM.2019.04.08

MOHAMMADI, M.; TORKASHVAND, A.M.; BIPARVA, P.; ESFANDIARI, M. The ability of layered double hydroxides for nitrate absorption and desorption in crop and fallow rotation. Global Journal of Environmental Science Management, v.7, n.1, p.59-78, 2020. https://doi. org/10.22034/gjesm.2021.01.05

MURTHY,K.B.; SUBBAIAH,K.V.Impactoffloral preservatives on anthocyanin content and vase life of cut gerbera cv. Savannah under ambient conditions. Journal of Pharmacognosy and Phytochemistry, v.9, n.4, p.900-903, 2020.

NAZARALIAN, S.; MAJD, A.; IRIAN, S.; NAJAFI, F.; GHAHREMANINEJAD, F.; LANDBERG, T.; GREGER,
M. Comparison of silicon nanoparticles and silicate treatments in fenugreek Plant. Physiology Biochemistry, v.115, p.25-33, 2017. https://doi.org/10.1016/j. plaphy.2017.03.009

PARK, J.W.; KIM, J.W.; KIM, W.S. Correlation between Calcium and Pectin Contents in Cut Gerbera During Scape Bending. Flower Research Journal, v.25, n.3, p.95-100, 2017.

PATEL, A.; MANKAD, A. Studies on postharvest self life of cut Chrysanthemum indicum and Tagetes erecta flowers. Indian Journal of Plant Physiology, v.7, n.3, p.292-294, 2002.

PERIK, R.J.; RAZÉ, D.; HARKEMA, H.; ZHONG, Y.; VAN DOOR, W.G. Bending in cut Gerbera jamesonii flower related to adverse water relations and lack of stem sclerenchyma development, not to expansion of the stem central cavity or stem elongation. Postharvest Biology and Technology, v.74, p.11-18, 2012. https://doi.org/10.1016/j. postharvbio.2012.06.009

PRUTHI, V.; GODARA, R.K.; BHATIA, S. K. Effect of different pulsing treatments on postharvest life of Gladiolus cv. happy end. Haryana Journal of Horticultural Science, v.30, n.3-4, p.196-197, 2001.

RALPH, J.; LUNDQUIST, K.; BRUNOW, G.; LU, F.; KIM, H.; SCHATZ, P.F.; MARITA, J.M.; HATFIELD, R.D.; RALPH, S.A.; CHRISTENSEN, J.H.; BOERJAN, W. Lignins: Natural polymers from oxidative coupling of 4-hydroxy phenyl propanoids. Phytochemistry Reviews, v.3, p.29-60, 2004. https://doi.org/10.1023/ B:PHYT.0000047809.65444.a4

RANE, M.; BAWSKAR, M.; RATHOD, D.; NAGAONKAR, D.; RAI, M. Influence of calcium phosphate nanoparticles, Piriformospora indica and Glomus mosseae on growth of Zea mays. Advances in Natural Sciences: Nanoscience and Nanotechnology, v.6, n.4, 045014, 2015. https://doi.org/10.1088/2043$6262 / 6 / 4 / 045014$

RANJBAR, P.; NAZARIDELJOU, M.; HOSSEINZADEH, A. Morpho-physiological responses of gerbera cut flower to foliar application of nano-silicon in soilless conditions. Journal of Science and Technology of Greenhouse Culture, v.8, n.2, p.27-38, 2017. https://doi.org/10.18869/ acadpub.ejgcst.8.2.27

SAUNDERS, J.A.; MCCLURE, J.W. The suitability of a quantitative spectrophotometric assay for phenylalanine ammonia-lyase activity in barley, buckwheat, and pea seedlings. Plant Physiology, v.54, n.3, p.412-413, 1974. https://doi.org/10.1104/pp.54.3.412

SIDDIQUI, M.H.; AL-WHAIBI, M.H.; SAKRAN, A.M.; BASALAH, M.O.; ALI, H.M. Effect of calcium and 
potassium on antioxidant system of Vicia faba L. under cadmium stress. International Journal of Molecular Sciences, v.13, n.6, p.6604-6619, 2012. https://dx.doi. org/10.3390\%2Fijms 13066604

SNYDER, G.H.; MATICHENKOV, V.V.; DATNOFF, L.E. Silicon. BARKER, A.V; PILBEAM, D.J. Silicon. Handbook of plant nutrition. CRC Press, 2016. p.567-584.

TAVAN, T.; NIAKAN, M.; NOURINIA, A. Effect of nanopotassium fertilizer on growth factors, photosynthetic system and protein content in wheat (triticum aestivum 1. Cv. N8019). Journal of Research Ecophysiology Iran, v.9, n.3, p.61-71, 2014.

TECHNICAL ASSOCIATION OF THE PULP AND PAPER INDUSTRY (TAPPI). TAPPI test methods. Testing Standards Performed by SGS-IPS. TAPPI, 1992.
VAN DOORN, W.G. Water relations of cut flowers. Horticulturae Reviews, v.18, p.1-85, 1997. https://doi. org/10.1002/9780470650608.ch1

VAN DOORN, W.G.; VASLIER, N. Wounding-induced xylem occlusion in stems of cut chrysanthemum flowers: roles of peroxidase and cathechol oxidase. Postharvest Biology and Technology, v.26, n.3, p.275-284, 2002. https://doi.org/10.1016/S0925-5214(02)00039-X

WANG, M.; GAO, L.; DONG, S.; SUN, Y.; SHEN, Q.; GUO, S. Role of silicon on plant-pathogen interactions. Frontiers in Plant Science, v.8, n.1, p.701-718, 2017. https://doi.org/10.3389/fpls.2017.00701

ZHANG, X.; ZHAO, Z.; RAN, G.; LIU, Y.; LIU, S.; ZHOU, B.; WANG, Z. Synthesis of lignin-modified silica nanoparticles from black liquor of rice straw pulping. Powder Technology, v.246, n.3, p.664-668, 2013. https:// doi.org/10.1016/j.powtec.2013.06.034 